\title{
Students' Self-Assessment on Hikmah Pedagogy in Islamic Education
}

\author{
Autoevaluación de los estudiantes sobre la pedagogía Hikmah en la educación islámica
}

Hafizhah Zulkifli

Universiti Kebangsaan Malaysia - Malaysia

Bangi, Malaysia

hafizhah_zulkifli@ukm.edu.my

Nor Alniza Azman

Teacher Education Institute - Malaysia

Selangor, Malaysia

alnizaazman712@gmail.com

\section{ABSTRACT}

Self-assessment is quintessential to monitor students' performance, particularly in getting feedback during the teaching and learning process. However, up to the present, research on students' self-assessment in Hikmah Pedagogy was limited to other subjects, such as Malay language, History, English language, and Science. Therefore, the objective of this research was to examine students' self-assessment on Hikmah (Wisdom) pedagogy based on gender and type of schools in Islamic education subject. The research applied a survey research design that involved 328 primary school students. The results revealed no statistically significant difference in the mean score for all constructs (speaking and listening, reasoning, manners in the community of inquiry, and open-mindedness) based on gender. On the contrary, the results derived from the one-way ANOVA tests for the types of school documented a significant difference in speaking and listening reasoning and open-mindedness. This research study may assist teachers in improving the teaching and learning process and help students to understand better in the classroom.

Keywords: Self-assessment; Hikmah pedagogy; gender; speaking and listening; reasoning

\section{RESUMEN}

La autoevaluación es esencial para supervisar el rendimiento de los estudiantes, especialmente para obtener información durante el proceso de enseñanza y aprendizaje. Hasta ahora, la investigación sobre la autoevaluación de los estudiantes en la pedagogía Hikmah se limitó a otras asignaturas, como la lengua malaya, la historia, la lengua inglesa y las ciencias. Por lo tanto, el objetivo de esta investigación fue examinar la autoevaluación de los estudiantes sobre la pedagogía Hikmah (Wisdom) en función del género y del tipo de escuelas en la asignatura de Educación Islámica. La investigación aplicó un diseño de encuesta en el que participaron 328 alumnos de primaria. Los resultados no revelaron ninguna diferencia estadísticamente significativa en la puntuación media de todos los constructos (hablar y escuchar, razonar, modales en la comunidad de investigación y apertura mental) en función del género. Por el contrario, los resultados derivados de las pruebas ANOVA de una vía para los tipos de escuela documentaron una diferencia significativa en hablar y escuchar, razonamiento y apertura mental. Este estudio de investigación puede ayudar a los profesores a mejorar el proceso de enseñanza y aprendizaje y a los alumnos a comprender mejor en el aula.

Palabras clave: Autoevaluación; pedagogía Hikmah; género; hablar y escuchar; razonamiento 
Self-assessment can be defined as a formative assessment that involves students' thinking about the quality of their work. It is a process of reflecting and judging their work or learning to improve performance as they identify the discrepancies between current and desired performance (Andrade \& Valtcheva, 2009; McMillan \& Hearn, 2008; Panadero Tapia \& Huertas, 2012). To be precise, self-assessment is a continuous process in which students (1) monitor and evaluate the quality of their thinking and behaviour when learning, and (2) identify strategies that enhance their knowledge and skills (McMillan \& Hearn, 2008).

For self-assessment, this research employed constructivist and cognitive learning theories. Constructivism is defined as "learning through the process of constructing meaning on how people make sense of their experience” (Merriam et al., 2007, p. 291). In other words, individuals create their new understanding based on the interaction between what they already know and believe with ideas and knowledge that they come into contact with (Resnick, 1989 as cited in Richardson, 2003).

Constructivist theory can be divided into two categories, such as cognitive constructivism and social constructivism (Nyikos \& Hashimoto, 1997; Richardson, 1997, 2003). The cognitive constructivist view by Piaget focused on individuals' construction of knowledge in responding to their interaction in the physical world, which implies a relatively solitary act apart from the social context that highlights the importance of individual cognitive development (Russell, 1993). Social interaction is "the imposition of adult functions on biologically determined stages of cognitive development, as declared by Piaget" (Russell, 1993, p. 189). On the other hand, the constructivist theory emphasised on the influence of social interaction as a driving force and requirement for individual cognitive development through internalisation of ideas encountered in the sociocultural surroundings by other constructivists, such as Lev Vygotsky (1978).

Constructivist learning theories are also applicable in the Hikmah Pedagogy. For example, the students need to answer the question given and discuss it with their friends. Thus, learning becomes a social activity that requires a connection with other human beings (Hein, 1991). Hikmah pedagogy was pioneered by Professor Dr. Rosnani Hashim, a professor from the International Islamic University Malaysia who had attended the first-hand formal training of a program by the Institute for the Advancement of Philosophy for Children (IAPC)'s founder, Matthew Lipman. In the early 1970s, Mathew Lipman introduced Philosophy for Children (P4C) as a form of philosophy-in-action in the classroom (Hashim et al., 2014). Lipman believes that philosophy is the appropriate tool to trigger and develop children's natural curiosity through the teaching and learning process. It can also help to develop children's higher-order thinking emphasizing critical, creative, ethical, and caring thinking.

Next, after professor Dr. Rosnani completed the training at the IAPC summer conference in August 2001, she experimented with $\mathrm{P}_{4} \mathrm{C}$ in a school and the results motivated her to continue implementing $\mathrm{P} 4 \mathrm{C}$ as a school holiday program. It was later when he remodeled the philosophical inquiry program for Muslim children based on Islamic ethical values and worldview rather than their first language (Hashim, 2017). Hashim further rebranded the P4C with a new name termed the Hikmah Programme. She felt that there was a need to rename the program to fit the Malaysian context because the Muslim society in Malaysia, typically, does not react well to the term "philosophy". She hoped that the term Hikmah would produce a positive ring as the word originates from the Islamic traditions (Hashim, 2017). 
Hikmah pedagogy is initiated from the beginning where students are seated in a u-shape formation. Then, the teacher provides stimulus materials of either short stories, posters, or videos to present stories. The students are given turns to read a short text. After that, the teacher will ask students to generate higher order thinking questions and write them on the whiteboard. The questions are classified into themes and discussed accordingly. Finally, the students need to answer the exercise questions and make a conclusion on the objective of the lesson (Hashim, 2018). After finishing the Hikmah pedagogy, students need to complete a self-assessment questionnaire. Self-assessment is a formative assessment to gain the feedback of the learning and make an improvement (Andrade \& Valtcheva, 2009).

There are various teaching strategies and pedagogies that can be implemented to make learning meaningful. Hikmah (Wisdom) pedagogy is one of the teaching pedagogies which aims to encourage students to master 21st-century learning skills, such as cognitive skills (critical thinking, creative thinking), collaborative skills, communication skills, and noble values. Several studies on Hikmah (Wisdom) pedagogy focused on its influence in enhancing critical thinking (Hashim \& Wan Yusoff, 2006; Othman \& Hashim, 2007, Abdullah, 2009; Hashim et al., 2017; Wan Yusoff, Hashim, Khalid, Hussein, \& Kamaluddeen, 2018; Zulkifli \& Hashim, 2020). Other studies highlighted qualitative research (Zulkifli \& Hashim, 2020) while fewer studies concentrated on Hikmah pedagogy in questioning skills (Zulkifli \& Hashim, 2019; Juperi, 2011; Alias, 2017).

Minimal research attention was directed to evaluating the teaching and learning assessment, especially in Hikmah (Wisdom) pedagogy. Research by Hashim et al,. (2019) discovered that there was a statistically significant difference in students' self-assessment before and after the implementation of Hikmah pedagogy in speaking and listening skills, as well as reasoning skills. Nevertheless, there was no statistically significant difference found for manners in the community of inquiry and open-mindedness.

Research by Hashim, Hussein, Khalid, Wan Yusof, Kamalludeen, and Zulkifli (2017) reported that the highest mean for primary school students' assessment was open-minded skills $(M=2.56)$, followed by manners in the community of inquiry $(M=2.55)$. Meanwhile, the lowest mean was communication $(M=2.18)$. As for the secondary school students, the highest score was openminded skills $(M=2.59)$, followed by manners in the community of inquiry $(M=2.50)$. Meanwhile, the lowest construct was reasoning $(M=2.22)$. These samples were taken from a primary school and a secondary school in Gombak which involved 128 from the former school and 265 from the latter.

Next, findings from the Hikmah feedback survey indicated that there was a positive influence of the Hikmah pedagogy on students' abilities to think, reason, and improve their communication skills for 188 Malaysian and international students at an international secondary school in Malaysia (Hashim et al., 2014).

Based on the existing studies, there is limited research on self-assessment, especially for primary school students. Only one or two of such studies were conducted, such as at Gombak and Kuala Lumpur international and primary schools. Although the studies emphasized various subjects, to date, those concentrating on Islamic education have received insufficient attention. Therefore, it is hoped that this research could fill the gap of location, sample, and teaching subject.

By examining students' self-assessment, one can understand the cognitive behavior of the students entirely after undergoing learning through Hikmah (Wisdom) pedagogy and make some improvements in teaching. With this knowledge, the researcher can better understand students' needs in learning. 
Henceforth, the objective of the current research was to identify the level of students' selfassessment on Hikmah Pedagogy in Islamic Education, to examine the significant difference between self-assessment and gender on Hikmah Pedagogy in Islamic Education, and to determine the significant difference between self-assessment and schools on Hikmah Pedagogy in Islamic Education.

\section{Methods}

The present researcher adopted a survey research design. The survey helps to identify important beliefs and attitudes of individuals, such as college students' beliefs about what constitutes abusive behaviours in dating relationships (Creswell, 2012). In this research, the survey helped to identify students' beliefs and attitudes, especially in self-assessment after the teaching and learning process.

The samples of this research were taken from Islamic students in the Hulu Langat district, Selangor, Malaysia. The population of Islamic students in primary schools in the Hulu Langat district was 2200 students. The researcher chose 328 Islamic education students randomly. According to Krejcie and Morgan's sample size table on 2200 population, there are 327 samples. The samples of 328 students are close to Krejie and Morgan's sample size table.

\section{Instrument}

An instrument of students' self-assessment checklist by Kuliyyah of Education, International Islamic University Malaysia, Centre for Teaching Thinking was used as the instrument in this research. The self-assessment checklist consists of four constructs with five items for the first construct of speaking and listening, six items for the second construct of reasoning, two items for the third construct of manners in the community of inquiry, and three items for the fourth construct. The students were required to rate themselves on a 3-point Likert scale as follows: $1=$ never; $2=$ =sometimes; $3=$ =always. In an attempt to interpret the mean scores, the following criteria were used:

Never: 1.00-1.66, Sometimes: 1.637-2.33, Always: 2.34-3.00

The reliability score of the students' self-assessment instrument and its Cronbach's alpha value for internal reliability was 0.79 . The researcher employed descriptive statistics such as mean and standard deviation, and inferential statistics which comprised independent-sample t-test and one-way ANOVA.

\section{Results}

\subsection{Demography of the respondents}

Table 1 shows the demography of the respondents. There were 140 male students and 188 female students. 136 students were from primary schools, 182 from private schools, and 10 from Chinese primary schools. 
Table 1: Demography of the respondents

\begin{tabular}{|c|c|c|c|}
\hline \multicolumn{2}{|c|}{ Demography } & N & Percent (\%) \\
\hline \multirow{2}{*}{ Gender } & Male & 140 & 42.7 \\
\cline { 2 - 4 } Types of School & Female & 188 & 57.3 \\
\cline { 2 - 4 } & Students in Primary School & 136 & 41.5 \\
\cline { 2 - 4 } & $\begin{array}{c}\text { Students in Primary Private } \\
\text { School }\end{array}$ & 182 & 55.5 \\
\cline { 2 - 4 } & $\begin{array}{c}\text { Students in Chinese Pri- } \\
\text { mary School }\end{array}$ & 10 & 3.0 \\
\hline
\end{tabular}

Source: Developed by author

\subsection{Level of students' self-assessment on Hikmah Pedagogy in Islamic Education}

The level of students' self-assessment on Hikmah Pedagogy in Islamic Education is shown in Table 2. The speaking and listening construct had the highestlevel $(M=11.34, S D=1.7)$, followed by reasoning $(M=9.5, S D=1.6)$. The lowest level was manners in the community of inquiry $(M=4.8$, $S D=0.97)$ while the overall construct was $(M=32.7, S D=4.23)$.

Table 2: Level of students' self-assessment

\begin{tabular}{|c|c|c|}
\hline Constructs & Mean & StandardDeviation \\
\hline Speaking and listening & 11.34 & 1.7 \\
\hline Reasoning & 9.5 & 1.6 \\
\hline $\begin{array}{c}\text { Manners in the Community of } \\
\text { Inquiry }\end{array}$ & 4.8 & 0.97 \\
\hline Open-Mindedness & 7.1 & 1.19 \\
\hline Overall & 32.7 & 4.23 \\
\hline
\end{tabular}

Source: Developed by author

\subsection{Independent sample t-test between students' self-assessment score based on gender}

An independent sample t-test is performed to compare the mean scores of two different groups of people or conditions. Thus, the hypothesis for this study is:

Ho1: There is no statistically significant difference between students' self-assessment scores for males and females.

The results in Table 3 display that there was no statistically significant difference in the mean scores for all constructs. To illustrate, speaking and listening for males ( $M=11.4, S D=1.86)$ and females $(M=11.2, S D=1.74)$, the reasoning for males $(M=9.54, S D=1.55)$ and females $(M=9.5$, $S D=1.66)$, manners in the community of inquiry for males $(M=4.85, S D=1.02)$ and females $(M=4.79$, $\mathrm{SD}=0.93)$, and open-mindedness for males $(\mathrm{M}=7.08, \mathrm{SD}=1.27)$ and females $(\mathrm{M}=7.11, \mathrm{SD}=1.14)$, which were based on gender, $p<.05$. The null hypothesis was accepted Ho1. It implied that there was no difference between male and female students regarding their self-assessment scores. 
Table 3: Independent sample t-test between students' self-assessment based on gender

\begin{tabular}{|c|c|c|c|c|c|}
\hline Constructs & $N$ & Mean & StandardDeviation & $t$ & Sig \\
\hline \multirow{2}{*}{$\begin{array}{l}\text { Speaking andliste- } \\
\text { ning }\end{array}$} & 140 & 11.4857 & 1.86017 & \multirow{2}{*}{1.25} & \multirow{2}{*}{.21} \\
\hline & 188 & 11.2340 & 1.74849 & & \\
\hline \multirow[t]{2}{*}{ Reasoning } & 140 & 9.5429 & 1.55647 & \multirow{2}{*}{.22} & \multirow{2}{*}{.82} \\
\hline & 188 & 9.5027 & 1.66357 & & \\
\hline \multirow{2}{*}{$\begin{array}{l}\text { Manners in theCom- } \\
\text { munity of Inquiry }\end{array}$} & 140 & 4.8500 & 1.02434 & \multirow{2}{*}{.47} & \multirow{2}{*}{.63} \\
\hline & 188 & 4.7979 & .93740 & & \\
\hline \multirow[t]{2}{*}{ Open-Mindedness } & 140 & 7.0857 & 1.27220 & \multirow{2}{*}{-.23} & \multirow{2}{*}{.81} \\
\hline & 188 & 7.1170 & 1.14562 & & \\
\hline
\end{tabular}

Source: Developed by author

\subsection{One-Way Anova between Self-Assessment Scores based on Different Types of School}

One-way analysis of variance is typically used when there is one independent (grouping) variable with three or more levels (group) and one dependent continuous variable. The hypothesis is:

$\mathrm{H}_{0} 2$ There is no statistically significant difference in students' self-assessment scores for primary schools, private primary schools, and Chinese primary schools.

One-way ANOVA analysis was conducted to explore the impact of types of school on levels of self-assessment. The results were derived from the tests among different types of schools, such as primary schools, private primary schools, and Chinese primary schools. Interestingly, Table 4 exhibits significant differences in the self-assessment scores of three different schools. There was a significantdifference at the $p<.05$ level in speaking and listening $(F=8.493, p=.000)$, reasoning $(F=7.011, p=.001)$, and open-mindedness $(F=7.377, p=.001)$. Nonetheless, there was no significant difference in manners in the communityof inquiry $(F=.515, p=.598)$.

The results of the Tukey posthoc test for Different Types of the school indicated that there was a significant difference for primary schools and private primary schools (Mean Difference $=0.62$, $p>.05$ ) for speaking and listening construct, for reasoning construct (Mean Difference $=0.59$, $\mathrm{P}>.05$ ), and open-mindedness construct (Mean Difference $=0.36, \mathrm{P}>.05$ ). However, there was no significant difference in the manner in the community of inquiry construct. 
Table 4: One-way Anova Test on Different Types of School

\begin{tabular}{|c|c|c|c|c|c|c|}
\hline & \multirow{3}{*}{$\begin{array}{c}\begin{array}{c}\text { Sum of } \\
\text { Square }\end{array} \\
52.53\end{array}$} & \multirow{3}{*}{$\begin{array}{r}\boldsymbol{d f} \\
2\end{array}$} & \multirow{3}{*}{$\begin{array}{l}\text { Mean } \\
26.26\end{array}$} & & \\
\hline & & & & & $\boldsymbol{F}$ & Sig. \\
\hline \multirow{3}{*}{$\begin{array}{l}\text { Speaking and lis- } \\
\text { tening }\end{array}$} & Between group & & & & 8.49 & .000 \\
\hline & Within group & 1005.22 & 325 & 3.09 & & \\
\hline & Total & 1057.75 & 327 & & & \\
\hline \multirow[t]{3}{*}{ Reasoning } & Between group & $35 \cdot 326$ & 2 & 17.66 & 7.011 & .001 \\
\hline & Within group & 816.29 & 324 & & & \\
\hline & Total & 851.62 & 326 & 2.379 & & \\
\hline \multirow{3}{*}{$\begin{array}{l}\text { Manners in the } \\
\text { Community of } \\
\text { inquiry }\end{array}$} & Between group & .980 & 2 & .490 & .515 & .598 \\
\hline & Within group & 309.40 & 325 & .952 & & \\
\hline & Total & 310.38 & 327 & & & \\
\hline \multirow[t]{3}{*}{ Open-Mindedness } & Between group & 20.430 & 2 & 10.215 & 7.377 & .001 \\
\hline & Within group & 450.046 & 325 & 1.385 & & \\
\hline & Total & 470.476 & 327 & & & \\
\hline
\end{tabular}

Source: Developed by author

\section{Discussions}

The levels of students' self-assessment on Hikmah Pedagogy in Islamic Education indicated that listening and speaking construct had the highest level, followed by reasoning. The lowest level was manners in the community of inquiry. The findings are consistent with those of Hashim, Hussein, and Imran (2014), i.e., the influence of Hikmah pedagogy could improve students' communication and reasoning skills. The research findings matched with Wan Yusoff's (2018) that Hikmah pedagogy could assist students who are from low-achiever classes in reasoning abilities, asking questions, clarifying meaning, giving examples, making conclusions, and inductive reasoning, as well as distinguishing and clarifying ideas.

The study was also approved by Hashim, Wan Yusoff, Hussein, Khalid, and Kamalludeen (2018) that the students were exemplary in metacognition, manners in the community of inquiry, and open-mindedness as seen from the teacher assessment of the students (Form Four). At the same time, there was a good improvement in listening and speaking, and manners in the community of inquiry construct for the Standard Four students. In contrast, Hashim et al. (2017) discovered the highest mean on students' self-assessment for open-mindedness and manners in the community of inquiry constructs while the lowest mean was listening and speaking for the t-test score.

Next, there was no difference in gender on students' self-assessment. It means that in selfassessment of the teaching and learning process, both male and female students have equal cognitive behaviour. Beyer (1990) added that when expectancies construct that becomes a mediator is controlled in self-evaluation, there is no significance in gender differences. In contrast, research by Pallier (2003) indicated that there were statistically significant differences in males and females as the former were more confident than the latter in cognitive ability.

The results derived from the tests among different types of schools showed significant differences in the self-assessment scores for three different schools in speaking and listening, reasoning, and open-mindedness. Nevertheless, there was no significant difference in manners in the community of inquiry. The findings also coincide with Hashim et al., (2019) on the significant difference in speaking and reasoning. On the other hand, manners in the community of inquiry and open- 
mindedness did not display any significant difference. Research by Hashim et al. (2017) supported that there were statistically significant differences in listening and speaking and manners in the community of inquiry. However, no significant differences were found in reasoning and openmindedness.

\section{Conclusion}

In conclusion, students rate themselves as always speaking, listening, and reasoning after the Hikmah Pedagogy while students sometimes practice manners in the community of Inquiry and openmindedness. The results also illustrate males and females have an equal score in self-assessment. Students also have significant differences in three constructs such as speaking and listening, reasoning and open-mindedness based on types of schools. The students' self-assessment is the key to more influential students' motivation and more distinguished achievement. Students used self-assessment to recognize what they have learnt and how much effort they must spend for success. Self-assessment is not only important for students, but also for teachers. Teachers can also use self-assessment for themselves. It is crucial to strive for their teaching accomplishment.

There are several limitations to this study. This study focuses on the level of self-assessment in gender and types of schools. Thus, we do not fully capture the demography of location, age, and status of socioeconomic. It is possible that other researchers will study the level of selfassessment in other demography in the future. Next, this study investigates self-assessment in cognitive behaviour only. Hence, the self-assessment is not fully covering the non-cognitive part. Upcoming studies should include non-cognitive parts to see different results. This research is a quantitative method using a survey research design. It is suggested that in the future, the researcher should use different methods such as qualitative methods such as a case study to explore self-assessment among students. Moreover, this study examines self-assessment from students' perspectives. In the forthcoming, the research can investigate the teachers' assessment of students.

\section{REFERENCES}

Abdullah, N. (2009). The pedagogy of philosophical inquiry as an approach to develop critical thinking and self-confidence: A case study of undergraduate students in IIUM (Doctoral dissertation). International Islamic University Malaysia.

Alias. H. (2017). Teaching thinking through stories from the Qur'an using philosophy for children method (Master's thesis). International Islamic University Malaysia.

Andrade, H. (2007). Self-assessment through rubrics. Journal of Educational Leadership, 65(4), 6063. https://www.ascd.org/el/articles/self-assessment-through-rubrics

Andrade, H., \& Du, Y. (2007). Student responses to criteria-referenced self-assessment. Assessment and Evaluation in Higher Education, 32(2), 159-181. https://doi.org/10.1080/02602930600801928

Andrade, H., \& Valtcheva, A. (2009). Promoting learning and achievement through self- assessment. Theory into Practice, 48(1), 12-19. https://doi.org/10.1080/00405840802577544

Beyer, S. (1990). Gender differences in the accuracy of self-evaluations of performance. Journal of Personality and Social Psychology, 59(5), 960-970. https://doi.org/10.1037/0022-3514.59.5.96

Boud, D. (1989). The role of self-assessment in student grading. Assessment \& Evaluation in Higher Education, 14(1), 20-30. https://doi.org/10.1080/0260293890140103 
Creswell, J. W. (2012). Educational research: Planning, conducting, and evaluating quantitative and qualitative research (4th ed.). Pearson.

Hashim, R. (2018). Pedagogi Hikmah bagi kemahiran insaniah kritis, kreatif, keprihatinan, komunikatif dan kolabotif: Panduan untuk pendidik. Centre for Teaching Thinking International Islamic University Malaysia.

Hashim, R., Hussien, S., \& Imran, A. M. (2014). Hikman (Wisdom) pedagogy and students' thinking and reasoning abilities. Intellectual Discourse, 22(2), 119-138. https://journals.iium.edu.my/ intdiscourse/index.php/id/article/view/6o8

Hashim, R., Hussein, S., Khalid, M., Wan Yusoff, W. M., Kamaludden, R., \& Zulkifli, H. (2017). Laporan kajian rintis program pedagogi hikmah di sekolah terpilih daerah Gombak: Bagi kemahiran berfikir kritis, kreatif, kolaboratif, komunikasi dan kepedulian. https://cutt.ly/1QShOJQ

Hashim, R., \& Wan Yusoff, W. M. (2006). P4C Development in Malaysia (Institute for the Advancement of Philosophy for Children). Newsletter, 10-11.

Hearn, J., \& McMillan, J. H. (2008). Student self-assessment: The key to stronger student motivation and higher achievement. Educational Horizons, 87, 40-49. https://doi. org/10.1080/0141620042000336611

Hein, G. (1991). Constructivist learning theory. The museum and the needs of people. [Conference] International Committee of Museum Educators Conference. http://www.exploratorium.edu/ IFI/resourses/constructivistlearning.html

Juperi, A. J. (2011). Philosophical inquiry in Islamic education and its effect in the development of questioning skills among secondary school students (Master's thesis). International Islamic University Malaysia.

Krejcie, R. V., \& Morgan, D. W. (1970). Determining sample size for research activities. Educational and Psychological Measurement, 30(3), 607-610. https://doi.org/10.1177/001316447003000308

Merriam, S. B., Caffarella, R. S., \& Baumgartner, L. M. (2007). Leaving in Adulthood: A Comprehensive guide (3rd ed.). John Wiley \& Sons.

Nyikos, M. \& Hashimoto, R. (1997). Constructivist theory applied to collaborative learning in Teacher Education: in Search of ZPD. Modern Language Journal, 81(4), 506-517. https://doi. org/10.2307/328893

Othman, M., \& Hashim, R. (2007). Critical thinking and reading skills: A comparative study of the reader response and the philosophy for children. Thinking: The Journal of Philosophy for Children, 18(2), 26-34. http://irep.iium.edu.my/26951/1/RH_Critical_Thinking\%26Reading_ Skills.PDF

Pallier, G. (2003). Gender differences in the self-assessment of accuracy on cognitive tasks. Sex Roles, 48(5-6), 265-276. https://doi.org/10.1023/A:1022877405718

Panadero, E., Tapia, J. A., \& Huertas, J. A. (2012). Rubrics and self-assessment scripts effects on self-regulation, learning and self-efficacy in secondary education. Learning and Individual Differences, 22(6), 806-813. https://doi.org/10.1016/j.lindif.2012.04.007

Pintrich, P. R. (2002). Motivation in education: Theory, research, and applications (2nd ed.). Merrill/ Prentice Hall.

Richardson, V. (Eds.). (1997). Constructivist teacher education: Building a world of new understanding. Falmer.

Richardson, V. (2003). Constructivist pedagogy. Teacher College Record, 105(9), 1623-1640. http:// dx.doi.org/10.1046/j.1467-9620.2003.00303.x 
Ross, J. A., Rolheiser, C., \& Hogaboam-Gray, A. (1998). Skills-training versus action research inservice: Impact on student attitudes to self-evaluation. Teaching and Teacher Education, 14(5), 463-477. http://hdl.handle.net/1807/30027

Russell, D.R. (1993). Vygotsky, Dewey, and externalism: Beyond the student/discipline dichotomy. Journal of Advanced Composition, 13, 173-197.

Shepard, L. A. (2001). The role of classroom assessment in teaching and learning (CSE Technical Report No. 517). https://nepc.colorado.edu/publication/role-classroom-assessment-teaching-andlearning

Vygotsky, L. S. (1978). Interaction between learning and development (M. Lopez-Morillas, Trans.). In M. Cole, V. John-Steiner, S. Scribner, \& E. Souberman (Eds.), Mind in society: The Development of Higher Psychological Processes (pp. 79-91). Harvard University Press.

Wan Yusoff, W. M. (2018). The impact of philosophical inquiry method on classroom engagement and reasoning skills of low achievers. Journal of Curriculum and Teaching, 7(1), 135-146. https:// doi.org/10.5430/jct.v7n1p135

Wan Yusoff, W. M., Hashim, R., Khalid, M., Hussein, S., \& Kamalludeen, R. (2018). The impact of Hikmah (Wisdom) Pedagogy on $21^{\text {st }}$ century skills of selected primary and secondary school students in Gombak District Selangor Malaysia. Journal of Education and Learning, 7(6), 100110. https://doi.org/10.5539/jel.v7n6p100

Zimmerman, B. J., \& Schunk, D. H. (2004). Self-regulating intellectual process and outcomes: A social cognitive perspective. In D. Y. Dai \& R. J. Sternberg (Eds.), Motivation, Motivation, Emotion and Cognition Integrative perspective on Intellectual Functioning and Development (pp. 323-349). Lawrence Erlbaum.

Zulkifli, H., \& Hashim, R. (2019). The development of questioning skills through (Wisdom) Pedagogy. Creative Education, 10(12), 2593-2605. https://doi.org/10.4236/ce.2019.1012187

Zulkifli, H., \& Hashim, R. (2020). Philosophy for children (P4C) in improving critical thinking in a secondary moral education class. International Journal of Learning, Teaching and Educational Research, 19(2), 29-45. https://doi.org/10.26803/ijlter.19.2.3

\section{AUTHORS}

Hafizhah Zulkifli. Doctor of Philisophy in Education. 2019. International Islamic University Malaysia, Malaysia. Master in Education. 2011. Universiti Kebangsaan Malaysia. Degree in Education. 2008. Universiti Kebangsaan Malaysia. Lecturer, Faculty of Education, 1 Nov 2011present

Nor Alniza Azman. Master in Islamic Education. Degree in Islamic Education.

\section{Conflict of interest}

No potential conflict of interest is reported by the authors.

\section{Funding}

This research was supported by the Faculty of Education, the National University of Malaysia,code GGPM-2020-007.

Acknowledgments 